\title{
THE SIGNIFICANCE OF ISLAMIC SOCIAL FINANCE IN STABILISING INCOME FOR MICRO-ENTREPRENEURS DURING THE COVID-19 OUTBREAK
}

\author{
Nik Hadiyan Nik Azman", Tajul Ariffin Masron² and Haslindar Ibrahim³ \\ ${ }^{1}$ School of Management, Universiti Sains Malaysia, Malaysia, nikhadiyan@usm.my \\ ${ }^{2}$ School of Management, Universiti Sains Malaysia, Malaysia, tams@usm.my \\ ${ }^{3}$ School of Management, Universiti Sains Malaysia, Malaysia, haslindar@usm.my
}

\begin{abstract}
The COVID-19 pandemic has heavily impacted micro-entrepreneurs worldwide. Although incentives and assistance funds have been provided by the government, these might only last for three months. The funds can be accessed through Islamic Social Finance (ISF) tools (Zakat, Waqf, Baytulmal, Ar-rahnu). Although ISF mitigates risks by providing fund assistance to micro-entrepreneurs, it is essential to know how far the assistance can support them and help them survive in their business. Therefore, this study intends to investigate the significance of Islamic social finance in stabilising micro-entrepreneurs' income during the COVID-19 pandemic, using the Partial Least Squares-Structural Equation Modeling (PLS-SEM) method. A survey consisting of 200 questionnaires was distributed to micro-entrepreneurs in three states in Malaysia between June and August 2020. The findings show that ISF has played an essential role in stabilising income among micro-entrepreneurs during the COVID-19 pandemic. Overall, zakat has the most robust, positive relationship with financial stability. This means that it is an essential tool being used by micro-entrepreneurs to stabilise their income during COVID-19.
\end{abstract}

Keywords: Islamic social finance, Covid-19, Micro-entrepreneurs.

JEL classification: G18; G21; G28.

Article history:

Received : October 8, 2020

Revised : February 26, 2021

Accepted : March 1, 2021

Available online : March 31, 2021

https://doi.org/10.21098/jimf.v7i0.1307 


\section{INTRODUCTION}

\subsection{Background}

The outbreak of COVID-19 in December 2019 has dramatically changed the world economic, public health, research, and medical community landscape. According to the OECD (Organization for Economic Co-operation and Development) 2020, its impact has been diverse and has automatically led to social and economic distress worldwide. The virus has also affected the stock market and business activities (Cheng, 2020).

As of mid-February 2020, China was bearing the brunt of COVID-19 morbidity and mortality. However, it very quickly spread to other Asian countries, and eventually all six continents. Consequently, as countries worldwide imposed nationwide lockdowns, production, operations, imports and exports have been disrupted (Majid, Hassan, Koshin, Musa \& Abdirahman, 2020). Some companies had to shut down to save costs, and employees lost their jobs. Malaysia has not been spared from the aftermath of COVID-19.

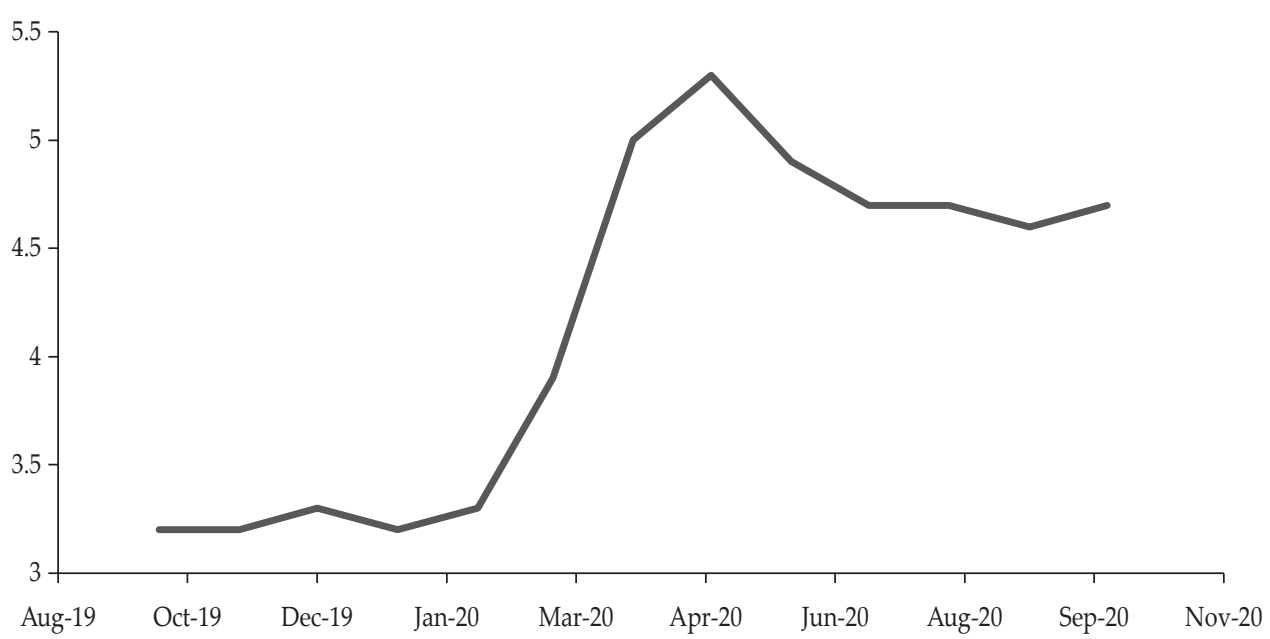

Source: Department of Statistics Malaysia (2020)

Figure 1.

Unemployment Rate in Malaysia (\%)

Malaysia's unemployment rate has increase drastically after the COVID-19 pandemic, from December 2019 until now (Figure 1). The rate was at its highest from January to April 2020 as an indirect effect of the nationwide lockdown (Movement Control Order or MCO) announced by the Prime Minister of Malaysia on 18 March 2020. The order was enforced under the Prevention and Control of Infectious Diseases Act 1988 and the Police Act 1967. The MCO was extended three times to slow down the COVID-19 transmission rate, each for another two weeks, until 12 May 2020. As a result, in order to survive some businesses needed to ask their employees to take a pay cut, to retrench employees, or worse, some needed to shut down their operations altogether (Cheng, 2020). According to Craven, 
Liu, Mysore \& Wilson (2020), the industries most affected were tourism, travel, manufacturing, construction, mining, and agriculture. Business operations and conduct are becoming the main challenges for micro-businesses or small traders to survive (Fazal, Al Mamun, Mansori \& Abir, 2019; Svatošová, 2017).

According to Figure 2, 67.8 per cent of companies and businesses reported that they had no source of income during the MCO period. While 12.3 per cent earned revenue through online sales, only 9.8 per cent made sales in physical shops. Besides encountering a decline in income, businesses have also faced issues related to employees' pay-outs $(21 \%)$, lack of customers $(18 \%)$, rental payments on premises $(17 \%)$, bank loan repayments $(10 \%)$ and lack of working capital (9\%).

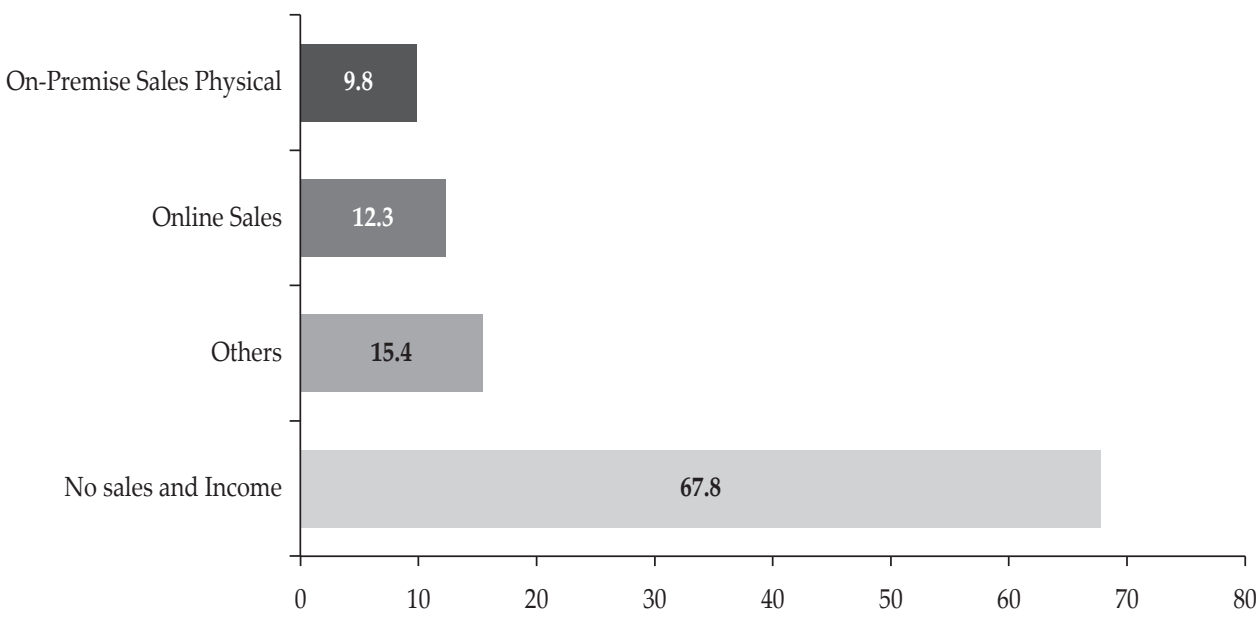

Figure 2.

Sources of Income for Businesses During the Movement Control Order (MCO) (\%)

In light of the above situation, the government has provided initiatives and stimulus packages to mitigate the impact of the pandemic. The initial RM 20 billion (4.9 billion USD) aimed to reduce the impact stemming from the pandemic, to stimulate people-based economic growth, and to encourage quality investments. In addition to the initial stimulus package, the Malaysian government then rolled out another package worth around RM 250 billion to safeguard people's welfare, support businesses, including SMEs, and strengthen the economy (the PRIHATIN economic stimulus package) (Yassin, 2020).

Besides relying on the Malaysian government's economic stimulus packages, Muslim micro-entrepreneurs opted for an alternative way of accessing funds, Islamic social finance (ISF). The ISF ecosystem provides opportunities to integrate traditional and shariah-compliant financial institutions. Its features and procedures are more flexible in assisting micro-entrepreneurs. The ISF sectors include Zakat, Waqf, Baytulmal and non-profit microfinance institutions such as Ar-rahnu. During the COVID-19 pandemic, these tools have been utilised by micro-entrepreneurs to help them survive. Table 1 gives details of the distribution of selected Islamic social finance by states during the pandemic. 
Table 1.

Selected ISF Distribution in Malaysia

\begin{tabular}{lc}
\hline \multicolumn{1}{c}{ Islamic Social Finance Institution } & Distribution (RM Million) \\
\hline Federal Territory Islamic Council (MAIWP) \& Center for Zakat & 34.41 \\
Collection (PPZ) & 20.2 \\
Terengganu Islamic Council and Malay Heritage & 16.7 \\
Kedah Zakat Board & 15 \\
Selangor Zakat Board (LZS) & 14.52 \\
Zakat Pulau Pinang & 14.35 \\
Perak Islamic Council and Malay Heritage & 12.6 \\
Kelantan Islamic Council & 12.2 \\
Pahang Islamic Council and Malay Heritage \& Center for Zakat & 7.4 \\
Collection of Pahang & 6 \\
Johor Islamic Council & 6 \\
Sabah Islamic Council & 4.3 \\
Baytulmal Sarawak & 4.26 \\
Negeri Sembilan Islamic Council (MAINS) & 3.98 \\
Zakat Melaka \& Melaka Islamic Council & \\
Perlis Islamic Council and Malay Heritage &
\end{tabular}

Source: Authors' compilation from the respective SRIC websites (2020)

Table 1 shows the enormous amount of funds channelled during MCO to the respective recipients. Since most of the micro-entrepreneurs are B40, these funds were able to help them. Basically, B40 is the bottom household income earner tier, representing $40 \%$ of the country's total income (low income). As indicated by the Malaysian government, B40 includes families that have an income of less than RM 4850. This group also has very limited savings for survival during the pandemic. The financial assistance received should ease their burden.

\subsection{Objective}

Mapping to understand the nature of the impacts during the COVID-19 pandemic, Islamic Social Finance (ISF) plays a part in assisting mitigation of the impact by providing shari'ah-compliant funding to achieve financial stability amongst micro-entrepreneurs. During the crisis, ISF, through its tools such as Zakat, Waqf, Baytulmal and Islamic microcredit institutions (Ar-rahnu) have assisted those in need. Although ISF supports micro-entrepreneurs by providing funds, it is imperative to know how far this assistance supports their survival in business. Therefore, this study aims to understand better the significance of Islamic social finance in stabilising micro-entrepreneurs' income during the COVID-19 outbreak. The first part of the study is the introduction, which consists of the background and objectives. This followed by the literature review, comprising theoretical and empirical reviews, together with the proposed framework. The third section presents the methodology, while the results and analysis are discussed in section four. Section five comprises the conclusion and recommendations. 


\section{LITERATURE REVIEW}

\subsection{Background Theory}

Maqasid al-shari'ah is the basis of all human actions and activities. It is based on the holy Qur'an and al-Sunnah (Mohammad \& Shahwan, 2013). According to ElMesawi \& Abdulaziz (2006), Maqasid al-shari'ah is related to human nature, which is stressed by five pillars: protection of life (Al-Hayah); protection of religion $(A l-$ Diin); protection of mind or intellect $\left(A l-{ }^{\prime} A q l\right)$; protection of wealth (Al-Mal); and protection of dignity (Al-Muru'ah). Indirectly, it also emphasises the enlightenment of Maslahah and Mafsada (Al-Ghazali, 1997). In a further refinement of the previous definition, Abu Zaharah (1997) divides Maqasid al-shari'ah into just three specific domains: educating the individual (Tahdhib al-Fard), establishing justice (Iqamah al-'Adl) and public interest (al-Maslahah). Studies which apply the same refining concept of Maqasid al-shari'ah include those of Chapra (2008), and Bayyah (2008). These studies also highlight the requirement of Maqasid al-shari'ah in economics development. According to Bahri, Aslam \& Wibowo (2019), the distribution of zakat funds related to mustahiq and the scope of work of microentrepreneurs, is directly related to two benefits, namely the protection of assets (maal) and maintaining sustainability (nasl). Adopting the Maqasid al-Shari'ah in line with the integration of Islamic social finance (ISF) tools plays a critical role in preserving and protecting Islamic jurisprudence principles. As mentioned in an Islamic social finance report (Islamic Research and Training Institutes, 2020), ISF integrates traditional and modern tools as waqf (Islamic endowment), zakat (compulsory alms), baitumal (house of wealth) and Ar-rahnu (micro-credit institutions). There are two types of Zakat: first that on wealth (Zakat-ul-maal) and second that on individuals (Zakat-ul-fitr). Efficiency in managing the zakat system will positively impact the socioeconomics of the poor and the needy. Offering alms to the poor and needy will contribute to the growth of the economy, as resources are channelled to members of society whose marginal propensity to consume is much higher (Ibrahim \& Ghazali, 2014). Based on this, this study develop a financial stability model to measure the significance of ISF tools among micro-entrepreneurs.

\subsection{Previous Studies}

An Islamic social finance (ISF) ecosystem has specific funding and investment instruments embedded within Sharī'ah (Islamic law) principles. These include waqf (Islamic endowment), zakat (compulsory alms), Baitumal (house of wealth) and Ar-rahnu (micro-credit institutions). The following sections review previous studies on ISF.

\subsubsection{Waqf}

Poverty is one of the crucial problems for a country. It is always been related to issues such as education, health, and shelter. Charity has the potential to overcome poverty, and the best form of this in Islam is Waqf. Waqf means to stop, contain, and preserve (Faizal, Ridhwan \& Kalsom, 2013). Innovative changes have been made to traditional waqf to cater for the needs and wellbeing of Muslims. During the COVID-19 pandemic, waqf is playing an essential role in cushioning the 
impact of the disease in socioeconomic terms, especially with regard to small traders and micro-entrepreneurs. Usama (2014) argues that waqf could provide financing for small traders to restructure their business during economic crises encountered by Muslim nations. Usama (2014), Ismail, Ab Malik \& Shafiai (2015), Siraj (2012) and Suhaimi, Ab Rahman \& Marican (2014) also discuss the role of waqf in empowering Muslims and providing a solution to poverty and insecurity, without depending solely on government intervention.

Waqf funds can be utilised in many ways. One of these is through proposing musharakah or mudharabah modes of financing. Cash waqf can be used to provide business capital for startups and for restructuring businesses. The profit earned in conducting business will be shared in an agreed ratio between both parties. Currently in Malaysia, the total assets of Waqf institutions are around RM 10 billion. During the COVID-19 outbreak, almost all the waqf institutions in Malaysia have provided for and contributed to ummah's stability. For example, RM 135 million was channelled to those affected by COVID-19 by Majlis Agama Islam Wilayah Persekutuan, and RM 369,200 in aid distributed to 18 selected hospitals in Malaysia, comprising medical tools such as syringe pump machines, N95 face masks, and personal protection equipment (PPE), together with other aid provided by Wakaf Selangor Muamalat. Considering the assistance and support given by waqf institutions, this study hypothesises that Waqf positively impacts financial stability:

H1: Waqf has a positive impact on financial stability.

\subsubsection{Zakat}

Zakat is an essential institution in the socioeconomic framework of Islam, being one of its five pillars. Zakat means growing, increasing, purifying, or giving one's wealth to gain Allah's blessing to make it grow in goodness. Muslims believe that all things belong to God and that wealth is held in trust by human beings (Bilo \& Machado, 2020). In Malaysia, the collection of Zakat was institutionalised by the state. This means that the respective state authority manages its collection and distribution, and organises assistance for the poor and others (Nadzri, AbdRahman \& Omar, 2012).

During the COVID-19 pandemic, zakat institutions have helped in reducing the burden on the government. As Al Anshory, Hudaefi, Junari, Zaenal \& Ramdhoni (2020) state, zakat plays an essential role as a philanthropic organisation in assisting the government in various sectors such as the economy, health and education and in social terms (Islamic preaching). Ahmad (2020) states that a total of RM153.24 million in zakat had been paid to zakat beneficiaries (asnaf) throughout the country during the Movement Control Order (MCO). This is in line with the Malaysian government's economic stimulus package known as "Prihatin", which aims to help households and businesses (Hidayat, 2020). Micro-entrepreneurs suffering a significant impact from COVID-19 have also received specific funds from zakat institutions through productive zakat (Ibrahim \& Ghazali, 2014). They have experienced business closures and cancellation of orders by customers at the last minutes, and have to bear the cost of loss or damage to products. This will hamper the spirit of doing business during the COVID-19 pandemic. Therefore, 
the assistance provided by zakat to small traders and micro-entrepreneurs will stabilise their business and help them survive during the pandemic. Consequently, it is hypothesised that Zakat has a positive impact on financial stability:

$\mathrm{H} 2$ : Zakat has a positive impact on financial stability.

\subsubsection{Baytulmal}

Baytulmal is an institution that deals with Islamic states' income and expenditure (Abdul Aziz, 2013), acting as an agent for development and social justice. This means that baytulmal develops a process to improve the living standards of Muslims. In Malaysia, during the COVID-19 pandemic, baytulmal helps those in need in various sectors, especially education, health, and socioeconomics. Funds of around RM 1.9 million have been distributed to students from families categorised as masakin or faqir. In terms of socioeconomic assistance, startup capital is provided to asnaf interested in doing business. With regard to microentrepreneurs' business among during COVID-19, baytulmal has offered an initiative called "asnafpreneurs" to help the asnaf affected. The main objective of this is to improve the standard of living of asnaf and integrate their living from receiving funds to contributors. Therefore, considering the benefits received by micro-entrepreneurs, the hypothesis is proposed that baytulmal has a positive impact on financial stability:

H3: Baytulmal has a positive impact on financial stability.

\subsubsection{Ar-ahnu}

Ar-rahnu is a Malaysian Islamic micro-credit institution. It has been operating in the country since 1992 as the Terengganu Islamic Pawnshop Corporation (MGIT), followed by Pemodalan Kelantan Berhad (PKB) and the Malaysian Islamic Economic Development Foundation (YaPEIM). Ar-rahnu is a microcredit institution that provides short-term financing to those in need. According to Nik Azman, Kassim \& Adeyemi (2016), micro-entrepreneurs are among the customers of ar-rahnu, as it provides cash quickly with a simple procedure. Most of the microentrepreneurs approaching ar-rahnu do so because of the shariah compliance of ar-rahnu institutions (Yahaya, 2020).

According to Nik Azman, Zabri, Masron \& Malim (2020), the uniqueness and efficiency of ar-rahnu are significant constructs in customers' adoption of ar-rahnu financing. Nik Azman et al. (2020) also investigated the significant relationship between ar-rahnu adoption and customers' financial wellbeing. During the COVID-19 pandemic, micro-entrepreneurs have been seriously affected, so approach the Ar-rahnu to help them survive in their business. Therefore, it is hypothesised that Ar-rahnu has a positive impact on financial stability:

H4: Ar-rahnu has a positive impact on financial stability.

\subsection{Financial Stability}

The status of financial stability is not easy to measure or define because of its interdependence with other elements, especially the financial system and the real 
economy (Gadanecz \& Jayaram, 2008). Previous studies' definitions of financial stability have depended on the variables used: Hawkins and Klau (2000), Nelson and Perli (2005) and Gray, Merton \& Bodie (2007) focus on market pressures, external vulnerability, and banking system vulnerability respectively. In the context of business, financial stability concerns its ability to facilitate and enhance economic processes, manage risks, and absorb shocks (Allen \& Wood, 2006).

From the micro-entrepreneurs' perspective, financial stability basically concerns the continuity of doing business from day to day (Gray et al., 2007). In the context of ISF, micro-entrepreneurs will receive the funds from it until their status changes to being a contributor to ISF funds. In the COVID-19 situation, microenterprises need to stay open and maintain their business. Micro-entrepreneurs need to consider valuing their profit, sales, assets, liabilities, and income. The status of doing business has changed to survival mode. Mitigating the impact of COVID-19 is the biggest challenges for micro-entrepreneurs to sustain their business operations. Currently, receiving and seeking funds as back-up capital is necessary to stabilise their financial status.

\subsection{Conceptual Framework}

The main goal of Islamic finance is often expressed in the one general term of Maqasid al-Shariah, terminology which simply describes the objectives of Shariah. It facilitates improvement and perfection in the conditions of social justice and will have positive impacts on all aspects of citizens' welfare. Its non-negotiable and vehement prohibitions on financial transactions based on interest, gambling, speculation, fraud, bribery, and corruption align with Maqasid al-Shariah. As mentioned in an Islamic social finance report (IRTI, 2020), ISF integrates traditional and modern tools, namely waqf (Islamic endowment), zakat (compulsory alms), baitumal (house of wealth) and Ar-rahnu (micro-credit institutions). Therefore, based on the theory and previous studies, this study proposes an Islamic social finance framework (Figure 3).

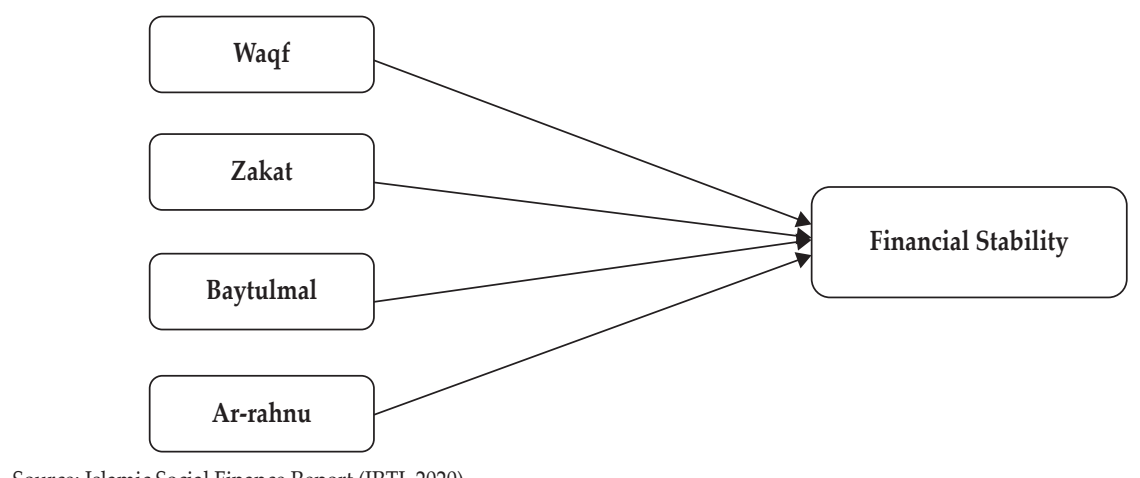

Source: Islamic Social Finance Report (IRTI, 2020)

Figure 3.

ISF towards Financial Stability Framework 


\section{METHODOLOGY}

\subsection{Data}

The survey respondents had to be Muslims micro-entrepreneurs using and receiving Islamic social finance tools to access funds. The survey was conducted from June 2020 to September 2020 employing a purposive sampling method, as the criteria for respondents were already set. The criteria included being a recipient of Islamic social finance, being Muslim and involved in micro business. The questionnaire was adapted from previous studies. Once the responses were received, the data were screened and coded accordingly. 176 questionnaires were returned, with 24 removed because of redundant and/or incomplete answers. The questionnaire was written in the Malay language only, as requested by the microentrepreneurs during the pilot test.

\subsection{Model Development}

After reviewing both the theoretical and empirical literature, a model of Islamic social finance stability for micro-entrepreneurs was developed in order to understand the critical issues concerning ISF tools. Based on the literature review, four tools were identified that may encourage their users to use Islamic social finance, namely zakat, waqf, Baytulmal and non-profit microfinance institutions such as Ar-rahnu. Measurement of the zakat (zakat 1-8), waqf (waqf 1-8), Baytulmal (Baytulmal 1-8) and Ar-rahnu (ar-rahnu 1-8) instruments was based on eight items: accessibility, availability, practicality, assessibility, applicability, Syariah governance, risks and efficiency. The questionnaire related to these ISF constructs was adapted from previous studies: with regard to ar-rahnu from Nik Azman et al. (2020) and Yahaya (2020); to zakat from Hashim, Mohamad \& Othman (2020), Bahri et al. (2019), and Pratama \& Sukmana (2020); to waqaf from Salarzehi, Armesh \& Nikbin (2010), Thaker, Amin, Thaker, Khaliq \& Pitchay (2020), and Lahsasna (2010); and to baytulmal from Rahman \& Ahmad (2011) and Possumah \& Ismail (2012). Details of the scale items are shown in Table 2.

Table 2.

Measurement Items for the Independent Variables

\begin{tabular}{lll}
\hline Construct & \multicolumn{1}{c}{ Item } & \multicolumn{1}{c}{ Sources } \\
\hline Ar-rahnu & $\begin{array}{l}\text { The accessibility of ar-rahnu attracts me to adopt it } \\
\text { (Arrahnu1) }\end{array}$ & $\begin{array}{l}\text { Nik Azman et al. (2020), } \\
\text { Yahaya (2020) }\end{array}$ \\
\hline & $\begin{array}{l}\text { I opt for Ar-rahnu as it is available everywhere (urban, } \\
\text { suburban and rural areas) (Arrahnu2) }\end{array}$ & \\
\hline & I consider ar-rahnu to be practical for my business (Arrahnu3) \\
& $\begin{array}{l}\text { I understand the assessibility criteria of fund receivers } \\
\text { (Arrahnu4) }\end{array}$ & \\
\hline $\begin{array}{l}\text { Considering the applicability of the simple Islamic terms, I } \\
\text { opt for ar-rahnu (Arrahnu5) }\end{array}$ & $\begin{array}{l}\text { I agree that the transactions of ar-rahnu comply with shari'ah } \\
\text { (Arrahnu6) }\end{array}$ \\
\hline $\begin{array}{l}\text { I have to bear the risks when dealing with ar-rahnu } \\
\text { (Arrahnu7) }\end{array}$ & $\begin{array}{l}\text { I believe staff at ar-rahnu are efficient at delivering funds } \\
\text { (Arrahnu8) }\end{array}$ \\
\hline
\end{tabular}


Table 2.

Measurement Items for the Independent Variables (Continued)

\begin{tabular}{|c|c|c|}
\hline Construct & Item & Sources \\
\hline \multirow[t]{8}{*}{ Zakat } & The accessibility of zakat attracts me to adopt it (Zakat1) & \multirow{8}{*}{$\begin{array}{l}\text { Hashim et al. (2020), } \\
\text { Bahri et al. (2019), } \\
\text { Pratama \& Sukmana } \\
(2020)\end{array}$} \\
\hline & $\begin{array}{l}\text { I opt for zakat as it available everywhere (urban, suburban } \\
\text { and rural areas) (Zakat2) }\end{array}$ & \\
\hline & I consider zakat to be practical for my business (Zakat3) & \\
\hline & $\begin{array}{l}\text { I understand the assessibility criteriasof fund receivers } \\
\text { (Zakat4) }\end{array}$ & \\
\hline & $\begin{array}{l}\text { Considering the applicability of the simple Islamic terms, I } \\
\text { opt for zakat (Zakat5) }\end{array}$ & \\
\hline & $\begin{array}{l}\text { I agree that the transactions of zakat comply with shari'ah } \\
\text { (Zakat6) }\end{array}$ & \\
\hline & I have to bear the risks when dealing with zakat (Zakat7) & \\
\hline & $\begin{array}{l}\text { I believe staff at zakat centres are efficient at delivering funds } \\
\text { (Zakat8) }\end{array}$ & \\
\hline \multirow[t]{8}{*}{ Waqf } & The accessibility of waqf attracts me to adopt it (Waqf1) & \multirow{8}{*}{$\begin{array}{l}\text { Salarzehi et al. (2010), } \\
\text { Thaker et al. (2020), } \\
\text { Lahsasna (2010) }\end{array}$} \\
\hline & $\begin{array}{l}\text { I opt for waqf as it available everywhere (urban, suburban } \\
\text { and rural areas) (Waqf2) }\end{array}$ & \\
\hline & I consider waqf to be practical for my business (Waqf3) & \\
\hline & $\begin{array}{l}\text { I understand the assessibility criteria of fund receivers } \\
\text { (Waqf4) }\end{array}$ & \\
\hline & $\begin{array}{l}\text { Considering the applicability of the simple Islamic terms, I } \\
\text { opt for waqf (Waqf5) }\end{array}$ & \\
\hline & $\begin{array}{l}\text { I agree that the transactions of waqf comply with shari'ah } \\
\text { (Waqf6) }\end{array}$ & \\
\hline & $\begin{array}{l}\text { I have to bear the risks when dealing with waqf institutions } \\
\text { (Waqf7) }\end{array}$ & \\
\hline & $\begin{array}{l}\text { I believe staff at waqf institutions are efficient at delivering } \\
\text { funds (Waqf8) }\end{array}$ & \\
\hline \multirow[t]{8}{*}{ Baytulmal } & $\begin{array}{l}\text { The accessibility of baytulmal attracts me to adopt it } \\
\text { (Baytulmal1) }\end{array}$ & \multirow{8}{*}{$\begin{array}{l}\text { Rahman \& Ahmad } \\
\text { (2011), Possumah \& } \\
\text { Ismail (2012) }\end{array}$} \\
\hline & $\begin{array}{l}\text { I opt for baytulmal as it available everywhere (urban, } \\
\text { suburban and rural areas) ((Baytulmal2) }\end{array}$ & \\
\hline & $\begin{array}{l}\text { I consider baytulmal to be practical for my business } \\
\text { (Baytulmal3) }\end{array}$ & \\
\hline & $\begin{array}{l}\text { I understand the assessibility criteria of fund receivers } \\
\text { (Baytulmal4) }\end{array}$ & \\
\hline & $\begin{array}{l}\text { Considering the applicability of the simple Islamic terms, I } \\
\text { opt for baytulmal (Baytulmal5) }\end{array}$ & \\
\hline & $\begin{array}{l}\text { I agree that the transactions of baytulmal comply with } \\
\text { shari'ah (Baytulmal6) }\end{array}$ & \\
\hline & $\begin{array}{l}\text { I have to bear the risks when dealing with baytulmal } \\
\text { (Baytulmal7) }\end{array}$ & \\
\hline & $\begin{array}{l}\text { I believe staff at baytulmal are efficient at delivering funds } \\
\text { (Baytulmal8) }\end{array}$ & \\
\hline
\end{tabular}


On the other hand, financial stability was measured based on capital, expansion, diversification, revenue and expenses, as adapted from DeGeorge \& Fayolle (2008) and Nik Azman et al. (2016). Details on the scale items are shown in Table 3.

Table 3.

Measurement Items for the Dependent Variable

\begin{tabular}{lll}
\hline Construct & \multicolumn{1}{c}{ Item } & Sources \\
\hline $\begin{array}{l}\text { Financial } \\
\text { Stability }\end{array}$ & $\begin{array}{l}\text { I can raise enough capital during COVID 19 by using Islamic } \\
\text { social finance instruments (FS1) }\end{array}$ & \\
\hline & $\begin{array}{l}\text { I can expand my business during COVID 19 by using Islamic } \\
\text { social finance instruments (FS2) }\end{array}$ & DeGeorge \& Fayolle \\
& $\begin{array}{l}\text { I can diversify my business by using Islamic social finance } \\
\text { instruments (FS3) }\end{array}$ & (2008), Nik Azman et al. \\
& $\begin{array}{l}\text { I can increase revenue when doing business during the } \\
\text { pandemic using Islamic social finance instruments (FS4) }\end{array}$ & \\
& $\begin{array}{l}\text { I can improve the costs of doing business during the } \\
\text { pandemic using Islamic social finance instruments (FS5) }\end{array}$ & \\
\hline
\end{tabular}

\subsection{Method}

The quantitative method was employed to investigate the issue. This method was preferred as COVID-19 is still new and it is challenging to obtain secondary data. Opting for qualitative data is also quite challenging as many procedures (SOPs) need to be adhered to. 200 self-administered survey questionnaires were distributed to micro-entrepreneurs in three states in Malaysia: Kedah, Kelantan, and Terengganu. These were chosen as they have most Muslim micro-entrepreneurs who have been affected during COVID-19 pandemic (Department of Statistics Malaysia, 2020). A self-administered delivery and collection questionnaire was used. The data were analysed using IBM SPSS for preliminary analysis (descriptive analysis). In order to analyse the research model, Partial Least Squares-Structural Equation Modeling (PLS-SEM) analysis was performed, employing SmartPLS 3.2 software (Ringle, Wende \& Becker, 2015). Following the recommended two-stage analytical procedure of Anderson and Gerbing (1988), the measurement model (validity and reliability of the measures) was tested, followed by an examination of the structural model (testing the hypothesised relationships) (see Hair, Sarstedt, Hopkins \& Kuppelwieser, 2014; Ramayah et al., 2011, 2013). To test the significance of the path coefficients and the loadings, the bootstrapping method (5000 resamples) was used (Hair et al., 2014).

\section{RESULTS AND ANALYSIS}

\subsection{Results}

The initial results concern the sample characteristics relating to gender, marital status, age, education level, and number of employees. Since all the respondents were Muslims and Malay, ethnicity and race factors. As can be seen in Table 4, most of the respondents were female (79.5\%), married (50\%), aged under $25(40.9 \%)$, had a highest education level of secondary school (58.5\%) and had no staff (42\%). 
It could therefore be concluded that most of the respondents were the female newcomers to the entrepreneur industry. In addition, the startup businesses were operated without staff for cost efficiency.

Table 4.

Sample Characteristics

\begin{tabular}{llc}
\hline Demographic Respondent & & Frequency [\%] \\
\hline Gender & Male & $36[20.5]$ \\
& Female & $140[79.5]$ \\
\hline Marital Status & Married & $88[50.0]$ \\
& Single & $87[49.4]$ \\
& Widowed & $1[0.6]$ \\
\hline Age & Under 25 & $72[40.9]$ \\
& $26-35$ & $51[29.0]$ \\
& $36-45$ & $40[22.7]$ \\
& $46-55$ & $6[3.4]$ \\
& Over 55 & $7[4.0]$ \\
\hline Education Level & Primary school & $3[1.7]$ \\
& Secondary school & $103[58.5]$ \\
& Certificates/Diploma & $49[27.8]$ \\
& Bachelor's degree & $20[11.4]$ \\
& Master's degree & $1[0.6]$ \\
\hline No. of Employees & No staff & $74[42.0]$ \\
& 1 & $50[28.4]$ \\
& 2 & $39[22.2]$ \\
& More than 2 & $13[7.4]$ \\
\hline
\end{tabular}

Note. $\mathrm{N}=176$

The measurement model was then reviewed. As shown in Table 3, according to Hair, Matthews, Matthews \& Sarstedt (2017), convergent validity is the degree to which indicators of a specific construct converge or share a high proportion of variance in common. The study assessed the convergent validity by the indicators suggested by Hair et al. (2017). They proposed to having more than 0.5 for average extracted variance (AVE), a cut off value for factor loading of 0.5 and all the composite reliability (CR) greater than 0.7 . The loadings for all the items were 0.5 and above. As seen in Table 5, AVE is higher than 0.5 and CR is greater than 0.7. At this stage, it was concluded that the construct met both reliability and convergent validities. 
Table 5.

Measurement Model

\begin{tabular}{|c|c|c|c|c|}
\hline Construct & Item & Loading & CR & AVE \\
\hline \multirow[t]{8}{*}{ Ar-Rahnu } & Arrahnu1 & 0.858 & 0.952 & 0.713 \\
\hline & Arrahnu2 & 0.883 & & \\
\hline & Arrahnu3 & 0.852 & & \\
\hline & Arrahnu4 & 0.905 & & \\
\hline & Arrahnu5 & 0.87 & & \\
\hline & Arrahnu6 & 0.819 & & \\
\hline & Arrahnu7 & 0.767 & & \\
\hline & Arrahnu8 & 0.794 & & \\
\hline \multirow[t]{8}{*}{ Zakat } & Zakat1 & 0.836 & 0.962 & 0.761 \\
\hline & Zakat2 & 0.897 & & \\
\hline & Zakat3 & 0.866 & & \\
\hline & Zakat4 & 0.889 & & \\
\hline & Zakat5 & 0.907 & & \\
\hline & Zakat6 & 0.889 & & \\
\hline & Zakat7 & 0.804 & & \\
\hline & Zakat8 & 0.886 & & \\
\hline \multirow[t]{5}{*}{ Financial Stability } & FS1 & 0.913 & 0.942 & 0.766 \\
\hline & FS2 & 0.942 & & \\
\hline & FS3 & 0.914 & & \\
\hline & FS4 & 0.751 & & \\
\hline & FS5 & 0.843 & & \\
\hline \multirow[t]{8}{*}{ Waqf } & Waqf1 & 0.776 & 0.951 & 0.707 \\
\hline & Waqf2 & 0.789 & & \\
\hline & Waqf3 & 0.864 & & \\
\hline & Waqf4 & 0.882 & & \\
\hline & Waqf5 & 0.921 & & \\
\hline & Waqf6 & 0.854 & & \\
\hline & Waqf7 & 0.892 & & \\
\hline & Waqf8 & 0.732 & & \\
\hline \multirow[t]{8}{*}{ Baytulmal } & Baytulmal1 & 0.822 & 0.95 & 0.703 \\
\hline & Baytulmal2 & 0.815 & & \\
\hline & Baytulmal3 & 0.899 & & \\
\hline & Baytulmal4 & 0.858 & & \\
\hline & Baytulmal5 & 0.857 & & \\
\hline & Baytulmal6 & 0.834 & & \\
\hline & Baytulmal7 & 0.825 & & \\
\hline & Baytulmal8 & 0.792 & & \\
\hline
\end{tabular}

Therefore, the study further assessed the model's discriminant validity. Ideally, according to Fornell and Larcker (1981), items should load more strongly on their constructs than on other constructs in the model. Moreover, the average variance (AVE) shared between each construct and its measures should be greater than the variance shared between the constructs. Its measures should be greater than the 
variance shared between the construct and other constructs. Table 6 shows the study's discriminant validity.

Table 6.

Discriminant Validity

\begin{tabular}{lccccc}
\hline & $\mathbf{1}$ & $\mathbf{2}$ & $\mathbf{3}$ & $\mathbf{4}$ & $\mathbf{5}$ \\
\hline 1. Ar-rahnu & 0.845 & & & & \\
2. Zakat & -0.929 & 0.872 & & & \\
3. Financial Stability & 0.56 & -0.52 & 0.875 & & \\
4. Waqf & 0.918 & -0.97 & 0.545 & 0.841 & \\
5. Baytulmal & 0.914 & -0.94 & 0.546 & 0.93 & 0.838 \\
\hline
\end{tabular}

Before analysing the structural model, nonlinear effects were used as a tool to check the robustness of the model (Table 7). According to Sarstedt, Ringle, Cheah, Ting, Moisescu \& Radomir (2019), nonlinear effects can be use to assess robustness for a PLS model. As they propose, this study used Ramsey's (1969) RESET on the latent variable scores extracted after the convergence of the original model's PLS-SEM algorithm. It was found that none of the partial regressions of FS on Ar-rahnu, Zakat, Waqf and Baytulmal $(F(1,170)=0.123, p=0.726)$ were subject to nonlinearities. Next, interaction terms were included to represent the quadratic effects. The results of the boostrapping with 5000 samples and using no sign changes showed that none of nonlinear effects was significant. Therefore, it was concluded that the linear effects of the model were robust.

Table 7.

Robustness

\begin{tabular}{lccc}
\hline & Coefficient & $p$-value & Ramsey's RESET \\
\hline Ar-rahnu*Ar-rahnu -> Financial & 0.567 & 0.253 & $(F(1,170)=0.123, p=0.726)$ \\
Stability & 0.223 & 0.7433 & \\
Zakat*Zakat -> Financial Stability & 0.892 & 0.1891 & \\
Waqf ${ }^{*}$ Waqf-> Financial Stability & 0.505 & 0.3308 & \\
Baytulmal*Baytulmal -> Financial & & & \\
Stability & &
\end{tabular}

The hypotheses proposed were then analysed. Four direct hypotheses were developed between the constructs. To test the significance level, $t$-statistics for all the paths were generated using the SmartPLS 3.0 bootstrapping function. Based on Table 8 , all the relationships were found to have $t$-values of $>1.28$, making the relationships significant at the 0.10 level. Specifically, the predictors of Ar-rahnu $(\beta=0.423, p<0.05)$, zakat $(\beta=0.577, p<0.05)$, waqf $(\beta=0.474, p<0.10)$, and baytulmal $(\beta=0.261, p<0.10)$, which explains 33.7\% in financial stability. Therefore, H1, H2, H3 and $\mathrm{H} 4$ are supported. The $\mathrm{R}^{2}$ value of 0.337 is above the 0.26 value, as suggested by Cohen (1988), which indicates a substantial model. 


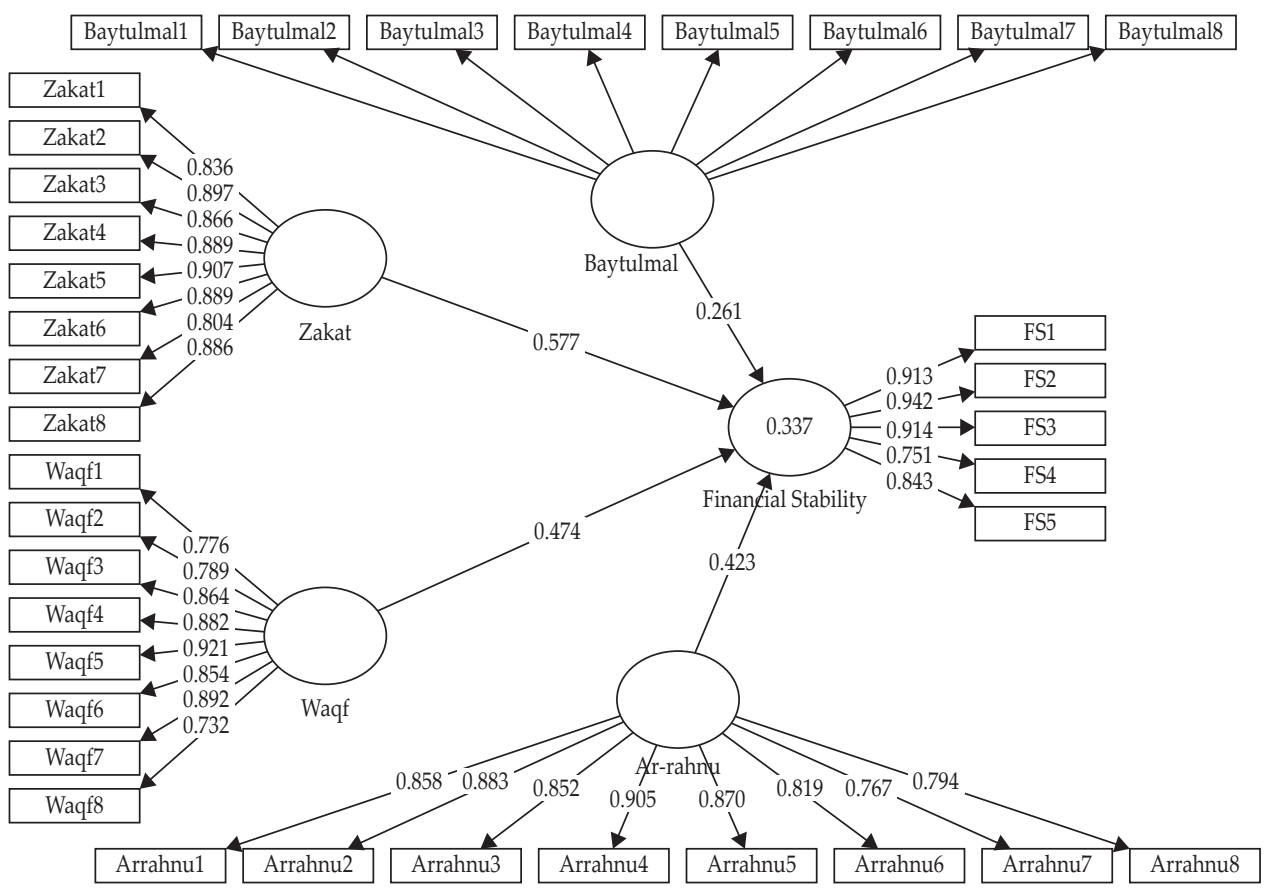

Figure 4.

Hypothesis of ISF

The effect sizes $\left(\mathrm{f}^{2}\right)$ were then assessed. As Sullivan and Feinn (2012) explain, the $p$-value only indicates the existence of the effect, but it does not reveal its size. Therefore, it is important to report both the substantive significance (effect size) and statistical significance ( $p$-value). To measure the effect size, Cohen (1988) suggests the following guidelines: 0.02 (small effect), 0.15 (medium effect) and 0.35 (large effect). In Table 8, it can be observed that all the predictors, Ar-rahnu (0.032), zakat (0.023), waqf (0.019), and baytulmal (0.010), have a small effect size on producing the $\mathrm{R}^{2}$ for financial stability. In addition, the predictive relevance of the model was examined using blindfolding procedures. As shown in Table 8 , the $Q^{2}$ value for financial stability is higher than 0 , at 0.241 , indicating that the model has sufficient predictive relevance (Hair et al., 2017). Moreover, Hair et al. state that the relative measure of predictive relevance between the values of 0.02 , 0.15 and 0.35 indicates that an exogenous construct has small, medium, or large predictive relevance for a specific endogenous construct. Table 8 also shows small $\mathrm{q}^{2}$ effect size for Ar-rahnu, zakat, waqf and baytulmal. 
Table 8.

Hypothesis Testing

\begin{tabular}{|c|c|c|c|c|c|c|c|c|c|c|}
\hline & $\begin{array}{c}\text { Std } \\
\text { Beta }\end{array}$ & $\begin{array}{l}\text { Std } \\
\text { Error }\end{array}$ & t-value & p-value & $\begin{array}{l}\text { BCI } \\
\text { LL }\end{array}$ & $\begin{array}{l}\text { BCI } \\
\text { UL }\end{array}$ & $\mathbf{R}^{2}$ & $\mathbf{f}^{2}$ & $\mathrm{Q}^{2}$ & $\mathbf{q}^{2}$ \\
\hline $\begin{array}{l}\text { Ar-Rahnu -> Financial } \\
\text { Stability }\end{array}$ & 0.423 & 0.226 & 1.869 & 0.031 & 0.030 & 0.757 & 0.337 & 0.032 & 0.241 & 0.021 \\
\hline $\begin{array}{l}\text { Zakat -> Financial } \\
\text { Stability }\end{array}$ & 0.577 & 0.352 & 1.641 & 0.051 & -0.021 & 1.115 & & 0.023 & & 0.011 \\
\hline $\begin{array}{l}\text { Waqf -> Financial } \\
\text { Stability }\end{array}$ & 0.474 & 0.305 & 1.553 & 0.060 & -0.169 & 0.812 & & 0.019 & & 0.009 \\
\hline $\begin{array}{l}\text { Baytulmal -> Financial } \\
\text { Stability }\end{array}$ & 0.261 & 0.178 & 1.466 & 0.072 & -0.075 & 0.501 & & 0.010 & & 0.004 \\
\hline
\end{tabular}

\subsection{Analysis and Discussion}

The impacts of COVID-19 have been diverse, from those on the health sector to those on the country's socioeconomic. Based on the results obtained by the study, ISF tools play an essential role in redeveloping and restructuring the business of micro-entrepreneurs. As explained by Shahwan et al. (2018), ISF functions to alleviate poverty and generate wealth and economic growth. Lawal and Ajayi (2019) also state that ISF is a platform for empowering and disbursing wealth in society. As shown in Table 6, the most robust relationship between ISF tools and financial stability is zakat $(\beta=0.577)$, followed by waqf $(\beta=0.474)$, ar-rahnu $(\beta=0.423)$ and baytulmal $(\beta=0.261)$.

Zakat is a vital medium for poor Muslims to obtain cash. Its crucial role is to minimise and prevent poverty by redistributing wealth to all parts of society. In the case of COVID-19, zakat institutions in Malaysia have shown various attributes in assisting in the need to survive (Hashim et al., 2020). Table 6 indicates that zakat has the most robust, positive relationship with financial stability. This means that it is an essential tool used by micro-entrepreneurs to stabilise their income during the COVID-19 outbreak. Most micro and small entrepreneurs receive benefits from zakat institutions. This finding is in line with Biancone and Radwan's (2018) study, which found that zakat could be a source to support entrepreneurship, especially during crises. In addition, Ab Rahman, Alias \& Omar (2012) also support this finding and explain that the giving of zakat to people in need is a tool to buffer the effects of recession in the economy.

Another strong and potential of the social impact on financial stability is waqf. The role of waqf is charitable, with no intention to reclaim funds. Its benefits can be evaluated, as it is one option for micro-entrepreneurs to obtain cash. As shown in Table 6, Waqf is another ISF tool available to micro-entrepreneurs during the COVID-19 pandemic. During the outbreak, Waqf institutions in Malaysia are undertaking their responsibilities for social development, raising awareness, increasing social investment, and enhancing the relationship between social security and social welfare. Waqf has provided a local economic environment to thrive. As argued by Ahmed (2007) and Kachkar (2017), waqf and zakat are both beneficial in providing microfinancing. While zakat makes offers using social savings directly to micro-entrepreneurs affected by COVID-19, without seeking 
any return, waqf (in term of cash waqf) are funds given based on mudarabah concepts, with revenue generated from investments used for charitable purposes. This is one way to ensure the continuity of waqf (Shaikh, Ismail \& Shafiai, 2017).

Islamic microfinance plays a role in combatting COVID-19. One of the Islamic microfinance tools is Ar-rahnu, which is also one of the most preferred choices among micro-entrepreneurs to ensure their financial stability. Ar-rahnu provides cash instantly to customers with quick and straightforward procedures (Nik Azman et al., 2016). During the COVID-19 pandemic, people lack cash but still have gold in hand. Instead of selling the jewellery that they have, they decide to ar-rahnu to pledge their jewellery. During the outbreak, the world gold price has been higher than during normal periods, meaning higher cash for pledgers. This is because the marhun value depends on the current gold price. In fact, during the pandemic, some of Malaysia's ar-rahnu institutions have increased the margin value by up to $80 \%$, with low service charges. Moreover, some ar-rahnu allow for the exemption of service charges and deferment of the redemption of collateral. These initiatives attract more customers, especially micro-entrepreneurs, to use ar-rahnu as a medium to obtain cash.

Although having the weakest relationship in comparison to the others, Baytulmal still has a positive relationship with financial stability. During COVID-19, Malaysia has introduced the "asnafpreneur" scheme, which is a way to assist asnaf become entrepreneurs; with the startup capital of RM 5,000 provided, asnaf have a chance to change their standard of living. The support given by baytulmal to micro-entrepreneurs, mostly Muslims, can transform their asnaf financial status. The study results show that ISF tools play a parallel role in contributing funds to micro-entrepreneurs to maintain their businesses. Although these tools have the same purpose, the mechanisms and approaches can differ. Moreover, the rules on applications also differ from state to state. In fact, some states in Malaysia do not have baytulmal institutions, while some only have three instead of having all, which might influence the results of the study.

\section{CONCLUSION AND RECOMMENDATIONS}

\subsection{Conclusion}

The COVID 19 pandemic has become a major challenge for "asnafpreneurs" who are involved in micro-enterprises. During this period they are facing capital shortages, damaged products, declining customer services and worst, business closures. In this struggle, ISF has lent a hand to assist the asnafpreneurs who have been affected by the outbreak (Hashim et al. 2020). Most micro and small entrepreneurs have received benefits from Islamic social finance institutions, as they are one of the sources of support for entrepreneurship, especially during a crisis. This shows that ISF has the ability to blend social objectives with business. The main objective of giving and sharing funds is to improve the standard of living of asnaf and integrate their living by receiving funds from zakat contributors. Therefore, it can be concluded that ISF plays an important role in stabilising the financial status of micro-entrepreneurs in Malaysia. 


\subsection{Recommendations}

Overall, zakat has the most robust, positive relationship with financial stability. This means that it an essential tool used by micro-entrepreneurs to stabilise their income during the COVID-19 outbreak. Regulators need to sustain the utilisation of zakat so that it will continue to have a positive impact on ummah, especially asnafpreneurs. During the crisis, practitioners, who are referred to as microentrepreneurs, need to be more innovative, and creative in diversifying their ways of doing business, thus creating solutions to tackle problems. Running traditional static businesses, micro-entrepreneurs need to upgrade their approach towards mobile business, fully utilising the free online platforms. COVID-19 could be treated as a blessing to generate more customers, as most people are staying at home and will have more time to browse online services. Academicians should enhance the study related to Islamic social finance, as awareness among Muslims is still at an insignificant stage. Considering the results from the study, Baytulmal has the weakest relationship, while Zakat, Waqf and Ar-Rahnu are developing quite a strong relationship with financial stability. This could be because people lack of awareness of baytulmal, whereas they are aware of the existence of Zakat, Waqf and Ar-rahnu. Academicians need to do more research on Islamic social finance in order to increase the awareness of Muslims of the existence of Batulmal institutions.

\section{REFERENCES}

Ab Rahman, A., Alias, M. H., \& Omar, S. M. N. S. (2012). Zakat institution in Malaysia: Problems and issues. Global Journal Al-Thaqafah, 2(1), 35-41.

Abdul Aziz, M. R. (2013). Introduction to Islamic institutions in economics and finance. Nilai, Malaysia: Universiti Sains Islam Malaysia (USIM) Publisher. ISBN 978967-0393-26-1.

Al Anshory, A. C., Hudaefi, F. A., Junari, U. L., Zaenal, M. H., \& Ramdhoni, R. (2020). The role of zakat in institution in preventing Covid-19. Policy Brief (March 2020). Jakarta: PUSKAS-BAZNAS. Retrieved on September 10,2020 , Available at: https://www.puskasbaznas.com/publ ications/policybrief/1186the-roleof-zakat-institution-in-preventing.

Ahmad, S. (2020). RM153.24 juta zakat diagih bantu asnaf sepanjang PKP [RM153.24 million in zakat was distributed to help asnaf during the PKP], Retrieved on September 10,2020 , available at: https://www.bharian.com.my/berita/ nasional/2020/04/676555/rm15324- juta-zakat-diagih-bantu-asnafsepanjangpkp.

Ahmed, H. (2007). Waqf-based microfinance: Realizing the social role of Islamic finance. World Bank, 6-7. Presented in International Seminar on "Integrating Awqaf in the Islamic Financial Sector", Singapore, March 6-7, 2007. Available at: https:// www.findevgateway.org/sites/default/files/publications/files/mfg-en-paperwaqf-based-microfinance-realizing-the-social-role-of-islamic-finance-2007. pdf.

Allen, W. A., \& Wood, G. (2006). Defining and achieving financial stability. Journal of Financial Stability, 2(2), 152-172. 
Anderson, J. C., \& Gerbing, D. W. (1988). Structural equation modeling in practice: A review and recommended two-step approach. Psychological Bulletin, 103(3), 411-423.

Bahri, E. S., Aslam, M. M. A., \& Wibowo, A. A. H. H. (2019). Maqasid al-shariah in micro-entrepreneurs development: An overview. Conference Proceedings of the $3^{\text {rd }}$ ICONZ International Conference of Zakat (pp. 258-267). Jakarta: PUSKAS-BAZNAS.

Bayyah, A. B. (2008). Maqasid al-Syari'ah fi al-Mu'amalat. Kaherah, Matabi'al-Madani al-Muassasah al-Su'udiyyah.

Biancone, P. P., \& Radwan, M. (2018). Sharia-compliant financing for public utility infrastructure. Utilities Policy, 52(June 2018), 88-94. https://doi.org/10.1016/j. jup.2018.03.006.

Bilo, C., \& Machado, A. C. (2020). The role of zakat in the provision of social protection: A comparison between Jordan and Sudan. International Journal of Sociology and Social Policy, 40(3/4), 236-248.

Chapra, M. U. (2008). The Islamic vision of development in the light of maqasid al-Shariah (Vol. 15). London: The International Institute of Islamic Thought. Available at: https://books.google.com.my/books?hl=id\&lr=\&id=TN-Xd9Es81sC\&oi=fnd\& pg=PP7\&dq=Chapra+(2008), +\&ots=DavdzSekfP\&sig=DHPhBCCVDt3MU9t7_N_XIDxI8o\&redir_esc=y\#v=onepage\&q=Chapra\%20(2008)\%2C\&f=false.

Cheng, C. (2020). COVID-19 in Malaysia: Economic impacts \& fiscal responses. Policy Brief, 1-20 (March 2020). Malaysia: Institute of Strategic and International Studies (ISIS). Available at: https://www.isis.org.my/2020/03/26/covid-19-inmalaysia-economic-impacts-fiscal-responses/.

Cohen, J. (1988). Statistical power analysis for the behavioral sciences (2nd ed.). Hillsdale, NJ: Lawrence Erlbaum Associates.

Craven, M., Liu, L., Mysore, M., \& Wilson, M. (2020, March 16). COVID-19: Briefing note, our latest perspective on the coronavirus outbreak. McKinsey \& Company. Retrieved from https://www.mckinsey.com/business-functions/ risk/our-insights.

DeGeorge, J. M., \& Fayolle, A. (2008). Is entrepreneurial intention stable through time? First insights from a sample of French students. International Journal of Entrepreneurship and Small Business, 5(1), 7-27.

El-Mesawi, M. E. T., \& Abdulaziz, A. B. (2006). Islamic Jurisprudence and the challenges of the 21st century: Maqāșid al-Sharī 'ah and its realization in contemporary societies. Intellectual Discourse, 14(2), 247-253.

Suhaimi, F. M., Ab Rahman, A., \& Marican, S. (2014), The role of share waqf in the socio-economic development of the Muslim community: The Malaysian experience.Humanomics, 30(3), 227-254.https://doi.org/10.1108/H-12-2012-0025.

Faizal, P. R. M., Ridhwan, A. A. M., \& Kalsom, A. W. (2013). The entrepreneur's characteristic from al-Quran and al-Hadis. International Journal of Trade, Economics and Finance, 4(4), 191-196. DOI: 10.7763/IJTEF.2013.V4.284.

Fazal, S. A., Al Mamun, A., Mansori, S., \& Abir, T. (2019). Entrepreneurial competencies and microenterprises performance: A study among the poor and low-income households in Malaysia. Academy of Entrepreneurship Journal, 25(4), $1-11$. 
Fornell, C., \& Larcker, D. F. (1981). Evaluating structural equation models with unobservable variables and measurement error. Journal of Marketing Research, 18(1), 39-50.

Gadanecz, B., \& Jayaram, K. (2008). Measures of financial stability-a review. Irving Fisher Committee Bulletin, 31(1), 365-383.

Gray, D. F., Merton, R., \& Bodie, Z. (2007). New framework for measuring and managing macrofinancial risk and financial stability. NBER Working Papers (No.13607). Massachusetts: National Bureau of Economic Research, Inc.

Hair, Jr. J. F., Sarstedt, M., Hopkins, L., \& Kuppelwieser, V. G. (2014). Partial least squares structural equation modeling (PLS-SEM): An emerging tool in business research. European Business Review, 26(2), 106-121. https://doi.org/10.1108/EBR10-2013-0128.

Hair, Jr. J. F., Matthews, L. M., Matthews, R. L., \& Sarstedt, M. (2017). PLSSEM or CB-SEM: Updated guidelines on which method to use. International Journal of Multivariate Data Analysis, 1(2), 107-123. https://doi.org/10.1504/ IJMDA.2017.087624.

Hashim, N., Mohamad, A., \& Othman, A. (2020). The challenges encountered by zakat recipients entrepreneurs. International Journal of Zakat and Islamic Philanthropy, 2(1), 157-164.

Hawkins, J., \& Klau, M. (2000). Measuring potential vulnerabilities in emerging market economies. BIS Working Paper No.91. Available at SSRN: http://dx.doi. org/10.2139/ssrn.849258.

Hidayat, T. (2020). Peran badan amil zakat nasional kota Banjarmasin dalam peningkatan perekonomian masyarakat. Management of Zakat and Waqf Journal (MAZAWA), 2(1), 50-61.

Ibrahim, P., \& Ghazali, R. (2014). Zakah as an Islamic micro-financing mechanism to productive zakah recipients. Asian Economic and Financial Review, 4(1), 117125.

Islamic Research and Training Institutes (2020). Islamic social finance report 2020. Retrieved from https:/irti.org/product/islamic-social-finance-report-2020/.

Ismail, M. A., Ab Malik, N. M. A. N., \& Shafiai, M. H. M. (2015). Empowering the peripheral ummah through waqf. The Journal of Muamalat and Islamic Finance Research, 12(1), 31-43.

Kachkar, O.A. (2017), Towards the establishment of cash waqf microfinance fund for refugees. ISRA International Journal of Islamic Finance, 9(1), 81-86.

Lahsasna, A. (2010). The role of cash waqf in financing micro and medium sized enterprises (MMEs): A new Islamic financial approach by using cash waqf model-testing the model on Malaysian mmes framework. Seventh International Conference-The Tawhidi Epistemology: Zakat and WaqfEconomy, Bangi (pp. 97-118). Retrieved from https://www.ukm.my/hadhari/wp-content/uploads/2014/09/ proceedings-seminar-waqf-tawhidi.pdf\#page $=106$.

Lawal, I. M., \& Ajayi, J. M. (2019). The role of Islamic social finance towards alleviating the humanitarian crisis in North-East Nigeria. Jurnal Perspektif Pembiayaan dan Pembangunan Daerah, 6(5), 545-558.

Majid, N., Hassan, S., Koshin, S. A, Musa, A. M., \& Abdirahman, K. (2020, June 11). Puntland and COVID-19: Local responses and economic impact. Conflict Research Management. Retrieved from http://eprints.lse.ac.uk/104813/1/CRP_ puntland_and_covid_19.pdf. 
Mohammad, M. O., \& Shahwan, S. (2013). The objective of Islamic economic and Islamic banking in light of Maqasid Al-Shariah: A critical review. Middle-East Journal of Scientific Research, 13(2013), 75-84. 10.5829/idosi.mejsr.2013.13.1885.

Nadzri, F. A. A., AbdRahman, R., \& Omar, N. (2012). Zakat and poverty alleviation: Roles of zakat institutions in Malaysia. International Journal of Arts and Commerce, 1(7), 61-72.

Nelson, W. R., \& Perli, R. (2005). Selected indicators of financial stability. 4th Joint Central Bank Research Conference on Risk Measurement and Systemic Risk, 8-9 November 2005. Frankfurt am Main: European Central Bank.

Nik Azman, N. H., Zabri, M. Z. M., Masron, T. A., \& Malim, N. A. K. (2020). The utilisation of Islamic fintech (I-Fintech) in promoting sustainable inclusive growth: Evidence from micro-entrepreneurs in Malaysia. Journal of Islamic Monetary Economics and Finance, 6(3), 555-576.

Nik Azman, H. N., Kassim, S., \& Adeyemi, A. A. (2016). Role of ar-rahnu as microcredit instrument in achieving financial self-sufficiency among women microentrepreneurs. Intellectual Discourse, 24(Special Issue), 365-385.

OECD. (2020). New OECD outlook on the global economy. Cardiff University. Retrieved March 2, 2020, from https://www.oecd.org/coronavirus.

Possumah, B. T., \& Ismail, A. G. (2012). Baitul mal and legal constraint: Public wealth management in Malaysian context. International Journal of Academic Research in Business and Social Sciences, 2(11), 27-52.

Pratama, M. F., \& Sukmana, R. (2020). Analisis faktor-faktor tpb dan religiosity terhadap willingness dalam berwakaf pengurus Muhammadiyah di Kota Surabaya. Jurnal Ekonomi Syariah Teori dan Terapan, 7(4), 633-645.

Rahman, R, A., \& Ahmad, S. (2011). Strategi pembangunan keusahawanan asnaf fakir dan miskin melalui agihan bantuan modal zakat (entrepreneurship developmentstrategy for poor and needy recipients on capital assistancethrough zakat distribution). Jurnal Pengurusan (UKM Journal of Management), 33(2011), 37-44.

Ramayah, T., Lee, J. W. C., \& In, J. B. C. (2011). Network collaboration and performance in the tourism sector. Service Business, 5(4), 411-428.

Ramayah, T., Yeap, J. A., \& Ignatius, J. (2013). An empirical inquiry on knowledge sharing among academicians in higher learning institutions. Minerva, 51(2), 131-154.

Ringle, C. M., Wende, S., \& Becker, J. M. (2015). SmartPLS 3 [computer software]. SmartPLS GmbH. California: Scientific Research.

Salarzehi, H., Armesh, H., \& Nikbin, D. (2010). Waqf as a social entrepreneurship model in Islam. International Journal of Business and Management, 5(7), 179-186.

Sarstedt, M., Ringle, C. M., Cheah, J. H., Ting, H., Moisescu, O. I., \& Radomir, L. (2019). Structural model robustness checks in PLS-SEM. Tourism Economics, 26(4), 531-554.

Shahwan, S., Shafii, Z., Mirza, A. A. I., Sapian, S., Salleh, S., Nawai, N., Ibrahim, N., $\&$ Haris, A. (2018). A review on product development of Islamic social finance in tijari sector. International Journal of Islamic Business, 3(2), 59-66.

Shaikh, S. A., Ismail, A. G., \& Shafiai, M. H. M. (2017). Application of waqf for social and development finance. ISRA International Journal of Islamic Finance, 9(1), 5-14. https://doi.org/10.1108/IJIF-07-2017-002. 
Siraj, S. A. (2012). An empirical investigation into the accounting, accountability and effectiveness of waqf management in the State Islamic Religious Councils (SIRCS) in Malaysia (Doctoral dissertation, Cardiff University).

Sullivan, G. M. \& Feinn, R. (2012). Using effect size-or why the p value is not enough. Journal of Graduate Medical Education, 4(3), 279-282.

Svatošová, V. (2017). Identification of financial strategy in small and medium-sized entrepreneurship. Acta Universitatis Agriculturae et Silviculturae Mendelianae Brunensis, 65(4), 1435-1453. https://doi.org/10.11118/actaun201765041435.

Thaker, M. A. M. T., Amin, M. F., Thaker, H. M. T., Khaliq, A., \& Pitchay, A. A. (2020). Cash waqf model for micro enterprises' human capital development. ISRA International Journal of Islamic Finance, ahead-of-print(ahead-of-print). https:// doi.org/10.1108/IJIF-08-2018-0091.

Usama, A. (2014). Waqf finance for micro projects. Journal of Awqaf, 27(November 2014), 115-162. Retrieved on February 20, 2020. Available at: https:// papers. ssrn.com/sol3/papers.cfm?abstract_id=3427854.

Yahaya, S. (2020). Intrinsic factors affecting the acceptance of Muslim small entrepreneurs in Kelantan towards ar-rahnu. International Journal of Business and Society, 21(2), 507-520.

Yassin, M. (2020, March 18). Perutusan khas perdana menteri COVID-19 [Special message by prime minister on Covid 19]. Retrieved from https://www.pmo. gov.my/2020/03/perutusan-khas-covid-19-18- mac-2020/. 